\title{
A Novel Acquired t(2;4)(q36.1;q24) with a Concurrent Submicroscopic del(4)(q23q24) in An Adult with Polycythemia Vera
}

\author{
Eigil Kjeldsen \\ Cancer Cytogenetic Section, HemoDiagnostic Laboratory, Department of Hematology, \\ Aarhus University Hospital, Tage-Hansens Gade 2, DK-8000 Aarhus C, Denmark; Eigil.Kjeldsen@clin.au.dk; \\ Tel.: +45-7846-7398; Fax: +45-7846-7399
}

Received: 6 June 2018; Accepted: 21 June 2018; Published: 25 June 2018

\begin{abstract}
Background: Polycythemia vera (PV) is a clonal myeloid stem cell disease characterized by a growth-factor independent erythroid proliferation with an inherent tendency to transform into overt acute myeloid malignancy. Approximately 95\% of the PV patients harbor the JAK2V617F mutation while less than $35 \%$ of the patients harbor cytogenetic abnormalities at the time of diagnosis. Methods and Results: Here we present a JAK2V617F positive PV patient where G-banding revealed an apparently balanced $\mathrm{t}(2 ; 4)$ (q35;q21), which was confirmed by 24-color karyotyping. Oligonucleotide array-based Comparative Genomic Hybridization (aCGH) analysis revealed an interstitial $5.4 \mathrm{Mb}$ large deletion at 4q23q24. Locus-specific fluorescent in situ hybridization (FISH) analyses confirmed the mono-allelic $4 \mathrm{q}$ deletion and that it was located on $\operatorname{der}(4) \mathrm{t}(2 ; 4)$. Additional locus-specific bacterial artificial chromosome (BAC) probes and mBanding refined the breakpoint on chromosome 2 . With these methods the karyotype was revised to 46,XX,t(2;4)(q36.1;q24)[18]/46,XX[7]. Conclusions: This is the first report on a PV patient associated with an acquired novel $t(2 ; 4)(q 36.1 ; q 24)$ and a concurrent submicroscopic deletion del(4)(q23q24). The study also underscores the benefit of combined usage of FISH and oligo-based aCGH analysis in characterizing chromosomal abnormalities. The present findings provide additional clues to unravel important molecular pathways in PV to obtain the full spectrum of acquired chromosomal and genomic aberrations, which eventually may improve treatment options.
\end{abstract}

Keywords: polycythemia vera; chromosomal abnormality; submicroscopic deletion del(4q); oligonucleotide array-based Comparative Genomic Hybridization (aCGH)

\section{Introduction}

Polycythemia vera (PV) is a clonal hematopoietic stem cell disorder classified as a $B C R / A B L 1$-negative myeloproliferative disease (MPD) with a variable risk of transformation into myelodysplasia (MDS) or acute myeloid leukemia (AML) [1,2]. It is characterized by a clonal increase in red blood cells, granulocytes and platelets, with erythrocytosis being the hallmark of the disease. The major contributor to the death of patients with PV appears to be AML/MDS, but there is no generally applicable way to predict which patient is likely to acquire this fatal complication.

Cytogenetic abnormalities have been found in approximately 13-35\% of patients with PV at the time of diagnosis [3-10]. The most common chromosomal abnormalities at diagnosis of PV are trisomies of chromosomes 1,8, and 9, as well as del(20q). Their role in the pathogenesis of the disease remains largely obscure and none of them are specific to PV. Although some reports have suggested that patients with PV carrying chromosomal aberrations at the time of diagnosis have a shorter survival and increased risk of AML/MDS compared to those with a normal karyotype [11] the predictive prognostic value of chromosomal aberrations has not yet been established in PV. 
A decade ago the first reports on oncogenic mutations in JAK2 appeared [12-16]. It has been found that more than $95 \%$ of the PV patients harbor the common JAK2V617F mutation although with varying allelic burden. The mutation is not specific to PV as it is also found in other MPN's although with lower frequency as well as in MDS / AML albeit more rarely. The JAK2V617F mutation is apparently not the disease-initiating event in humans, although the mutation in mice models has been found to induce a PV-like phenotype [17]. Still, no genetic defect entirely specific to PV has been identified.

Here we utilized several fluorescent in situ hybridization (FISH) applications an oligonucleotide array-based Comparative Genomic Hybridization (aCGH) analysis in combination to characterize a JAK2V617F positive PV patient harboring the novel acquired $\mathrm{t}(2 ; 4)(\mathrm{q} 36.1 ; \mathrm{q} 24)$ and a concurrent interstitial microdeletion at 4q23q24.

\section{Results}

\subsection{Clinical Description}

A 64-year-old female presented with a weight loss of 2-3 kg over a period of 3 months, pruitus and intermittent night sweat. Biochemical analysis revealed a hemoglobin concentration of $13.2 \mathrm{mmol} / \mathrm{L}$ (reference interval (RI) females: 7.3-9.5) and hematocrit $>0.60$ (RI females: 0.35-0.46). The platelet count was $372 \times 10^{9} / \mathrm{L}$ (RI: $165-400 \times 10^{9} / \mathrm{L}$ ), and the leucocyte count was $10.9 \times 10^{9} / \mathrm{L}$ (RI: $3.5-10.0 \times 10^{9} / \mathrm{L}$ ). The reticulocyte count was increased at $145 \times 10^{9} / \mathrm{L}$ (RI: $31-97 \times 10^{9} / \mathrm{L}$ ). The plasma erythropoietin was suppressed at $<1.0$ IU/L (RI: 5-30 IU/L). A bone marrow biopsy displayed features characteristic of PV with trilineage hyperplasia. The spleen was not enlarged upon clinical examination. The patient had a JAK2V617F mutation with an allelic burden of $71 \%$ and FISH excluded $B C R-A B L 1$ fusion gene. The patient was treated with phlebotomy, acetylsalicylic acid and required cytoreductive therapy with hydroxyurea or pegylated interferon alfa-2a due to intermittent thrombocytosis and leucocytosis during disease course (Supplementary Figure S1). The total follow-up time was 64 months and she is now in continuous treatment with phlebotomy, hydroxyurea and acetylsalicylic acid.

\subsection{Cytogenetic Analyses}

The karyotype, examined by G-banding analysis combined with 24-color karyotyping and mBanding analysis with chromosome 2 probes, was pseudodiploid harboring an apparently balanced reciprocal translocation between chromosomes 2 and 4 described as 46,XX,t(2;4)(q35;q21)[18]/46,XX[7] (Figure 1). To establish whether this translocation was constitutional or belonged to the malignant clone a peripheral blood sample was requested. G-banding after phytohaemagglutinin (PHA)-stimulated culturing showed a normal female karyotype 46,XX[25] (data not shown) indicating that the aberrant $t(2 ; 4)$ belongs to the malignant clone.

\subsection{Oligo-Based Array Comparative Genomic Hybridization (CGH) Analysis}

High-resolution oligo-based aCGH (oaCGH) analysis revealed an approximately $5.4 \mathrm{Mb}$ large deletion at chromosome 4 band region q23 to q24 (Figure 2A,B). The minimal region of deletion encompassed the following probes A_16_P36844152 to A_16_P36856072, mapping from 101,572,440 bp to $106,955,633 \mathrm{bp}$ and the maximal region of deletion encompassed probes A_16_P368440787 to A_16_P16801426 mapping from 101,550,452 bp to $106,975,209$ bp. The deleted region affected 40 RefSeq genes including TET2 and CXXC4 (Table 1). It is to be noted that the aCGH analysis did not disclose any further copy number alterations, neither on chromosome 2 . 
A

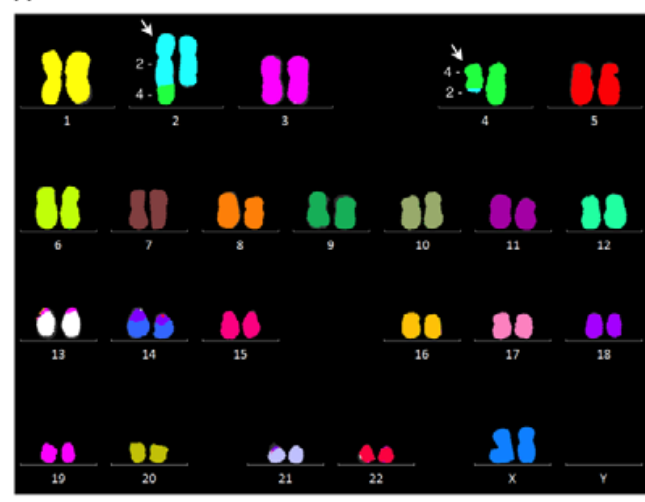

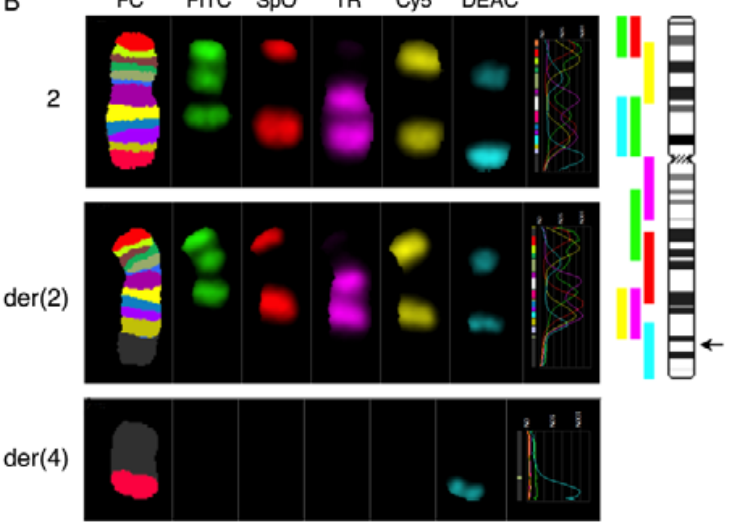

Figure 1. Multi-color Fluorescence in Situ Hybridization (FISH). (A) 24-color karyotyping revealed the translocation $\mathrm{t}(2 ; 4)$. White arrows indicate the derivative chromosomes. (B) mBanding analysis of chromosomes 2 . The single-color gallery tool in ISIS software shows assigned false colors (FC) and individual color schemes of labeled chromosomes arranged in their capture sequence FITC (fluorescein isothiocyanate), SpO (spectrum orange), TR (Texas red), Cy5 (cyanine), DEAC (7-diethylaminocoumarin-3-carboxylic acid, succinimidyl ester). Upper row shows the normal chromosome 2, middle row shows the $\operatorname{der}(2) \mathrm{t}(2 ; 4)$ and lower row show the $\operatorname{der}(4) \mathrm{t}(2 ; 4)$ from the patient's karyotype. The right-hand side shows a schematic representation of the localization of the different multicolor probes of XCyte 2 relative to the ideogram of chromosome 2 together with breakpoint marked by the arrow.

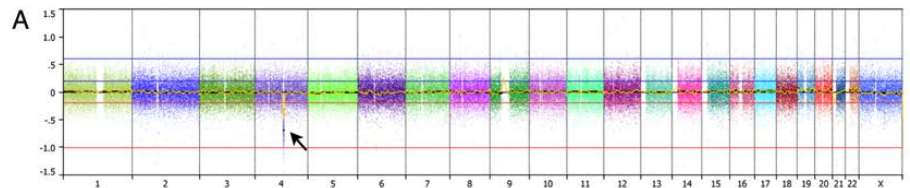

B
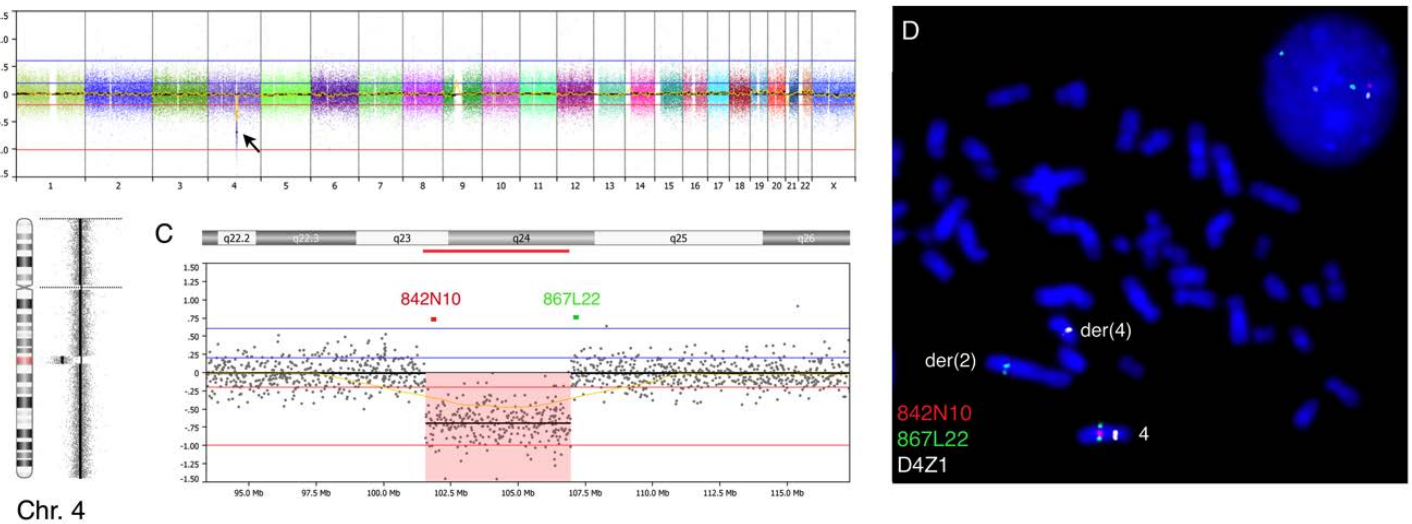

Figure 2. Oligo-based array Comparative Genomic Hybridization (oaCGH) analysis and FISH validation. (A) Whole genome view of the bone marrow sample showing a submicroscopic deletion at chromosome 4 indicated by the arrow. Horizontal blue lines indicate $\log _{2}$ ratios +0.24 and +0.60 and red lines indicate $\log _{2}$ ratios -0.24 and -1.0 . The $\mathrm{X}$-axis at the bottom indicates chromosomal position. (B) Chromosome view of chromosome 4 with deletion at 4q23-q24 indicated by an arrow and ideogram of chromosome 4 to the left. (C) A zoom view of the deleted region as indicated by red shade corresponding to the deletion's maximal chromosomal position. The red and green bars indicate the position of FISH probes used for validation. (D) FISH using BAC (Bacterial Artificial Chromosomes) probes RP11-842N10 (red) and RP11-867L22 (green) at 4q23 and 4q24, respectively, and centromeric probe D4Z1 (aqua) confirms the interstitial mono-allelic deletion and translocation in nuclei and metaphases from the patient. 
Table 1. Genes located in the deleted region on chromosome 4.

\begin{tabular}{|c|c|c|c|c|}
\hline Gene Symbol & Chromosome & Start & End & Length (bp) \\
\hline EMCN & chr4 & $101,535,520$ & $101,658,273$ & 122,754 \\
\hline LINC01216 & chr4 & $101,800,458$ & $101,815,293$ & 14,836 \\
\hline DKFZp761L0516 & chr4 & $102,163,609$ & $102,487,057$ & 323,449 \\
\hline РPР3СA & chr4 & $102,163,609$ & $102,487,651$ & 324,043 \\
\hline MIR8066 & chr4 & $102,380,974$ & $102,381,052$ & 79 \\
\hline FLJ20021 & chr4 & $102,487,956$ & $102,489,063$ & 1108 \\
\hline AK000028 & chr4 & $102,487,959$ & $102,489,062$ & 1104 \\
\hline BANK1 & chr4 & $102,560,140$ & $103,214,992$ & 654,853 \\
\hline SLC39A8 & chr4 & $103,391,220$ & $103,485,678$ & 94,459 \\
\hline NFKB1 & chr4 & $103,641,517$ & $103,757,507$ & 115,991 \\
\hline MANBA & chr4 & $103,771,690$ & $103,901,196$ & 129,507 \\
\hline LOC102723704 & chr4 & $103,917,265$ & $103,939,844$ & 22,580 \\
\hline CR618043 & chr4 & $103,934,626$ & $103,936,350$ & 1725 \\
\hline UBE2D3 & chr4 & $103,934,619$ & $104,009,491$ & 74,873 \\
\hline AK093356 & chr4 & $103,968,428$ & $103,984,352$ & 15,925 \\
\hline CISD2 & chr4 & $104,009,575$ & $104,033,412$ & 23,838 \\
\hline NHEDC1 & chr4 & $104,025,643$ & $104,160,325$ & 134,683 \\
\hline SLC9B1 & chr4 & $104,025,641$ & $104,160,345$ & 134,705 \\
\hline NHEDC2 & chr4 & $104,160,837$ & $104,217,379$ & 56,543 \\
\hline SLC9B2 & chr4 & $104,166,096$ & $104,217,977$ & 51,882 \\
\hline BDH2 & chr4 & $104,218,230$ & $104,240,473$ & 22,244 \\
\hline UNQ6308 & chr4 & $104,218,230$ & $104,240,473$ & 22,244 \\
\hline CENPE variant protein & chr4 & $104,278,956$ & $104,281,020$ & 2065 \\
\hline CENPE & chr4 & $104,246,411$ & $104,339,015$ & 92,605 \\
\hline LOC101929448 & chr4 & $104,565,647$ & $104,580,334$ & 14,688 \\
\hline TACR3 & chr4 & $104,730,073$ & $104,860,422$ & 130,350 \\
\hline AK093871 & chr4 & $105,609,014$ & $105,612,315$ & 3302 \\
\hline CXXC4 & chr4 & $105,608,911$ & $105,635,507$ & 26,597 \\
\hline AK094561 & chr4 & $105,631,570$ & $105,816,794$ & 185,225 \\
\hline LOC101929468 & chr4 & $105,631,570$ & $105,838,198$ & 206,629 \\
\hline TET2 & chr4 & $106,286,480$ & $106,420,409$ & 133,930 \\
\hline PPA2 & chr4 & $106,509,682$ & $106,614,676$ & 104,995 \\
\hline BC008246 & chr4 & $106,612,473$ & $106,614,625$ & 2153 \\
\hline EEF1AL7 & chr4 & $106,625,311$ & $106,626,956$ & 1646 \\
\hline ARHGEF38-IT1 & chr4 & $106,702,196$ & $106,710,841$ & 8646 \\
\hline FLJ20184 & chr4 & $106,693,225$ & $106,772,286$ & 79,062 \\
\hline ARHGEF38 & chr4 & $106,693,225$ & $106,821,519$ & 128,295 \\
\hline AK125951 & chr4 & $106,799,802$ & $106,821,519$ & 21,718 \\
\hline INTS12 & chr4 & $106,823,233$ & $106,849,330$ & 26,098 \\
\hline GSTCD & chr4 & $106,849,389$ & $106,988,331$ & 138,943 \\
\hline
\end{tabular}

Bp: base pairs.

\subsection{Validation by FISH Analyses}

To validate the above aCGH findings we performed FISH analysis using the bacterial artificial chromosomes (BAC)-based probes RP11-842N10 and RP11-867L22 together with centromeric probe D4Z1 (Figure 2C,D). This analysis confirmed the mono-allelic nature of the deletion in both metaphases and interphase nuclei and that the deletion involved the same chromosome 4 derivative being involved in the $t(2 ; 4)$. After counting of 200 nuclei we found that 150 nuclei exhibited a 2G1R2A pattern, indicating that $75 \%$ of the cells carried the deletion in the diagnostic sample. Fluorescence In Situ Hybridization on PHA-stimulated cultured white blood cells from peripheral blood with the probes RP11-842N10, RP11-867L22, and D4Z1 exhibited a normal signal pattern 2G2R2A in 100\% of interphase nuclei and on metaphases demonstrating that the observed abnormalities are acquired and belong to the abnormal hematopoietic cells. 


\subsection{Breakpoint Mapping by FISH Analyses}

To establish the breakpoint region on chromosomes 2 and 4 more precisely we used a panel of BAC-based probes in different combinations (Table 2 and Figure 3). From these FISH analyses we were able to determine that the breakpoint region on chromosome 2 is located within the BAC-probe RP11-79C2 and on chromosome 4 within the BAC-probe RP11-13F20.

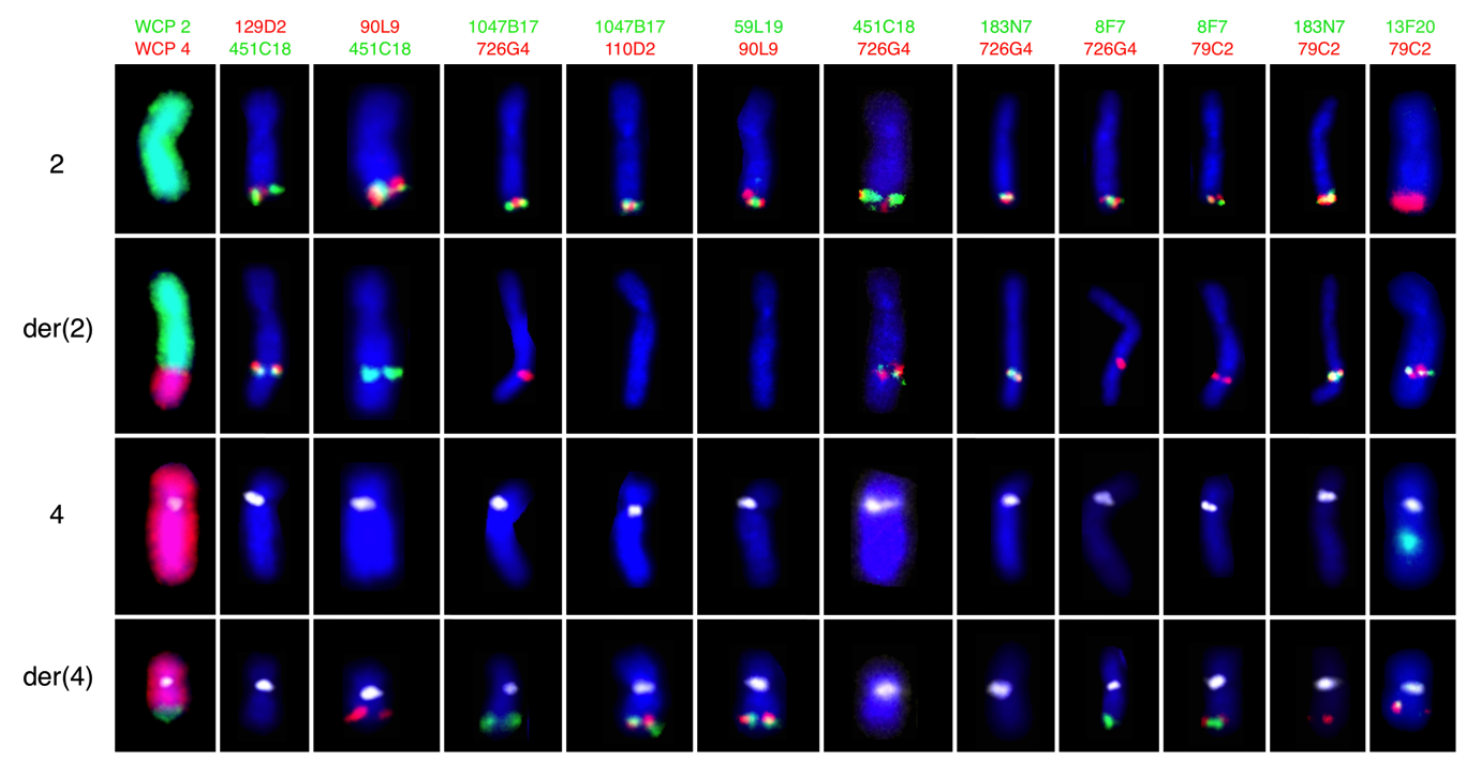

Figure 3. Break point mapping with FISH probes. Partial karyograms of normal chromosome 2, $\operatorname{der}(2) t(2 ; 4)$, normal chromosome 4 , and $\operatorname{der}(4) \mathrm{t}(2 ; 4)$ arranged from top to bottom showing FISH results after hybridization using respective dual color probe sets as indicated at the top. WCP indicates whole chromosome painting, and chromosome 4 is indicated by the centromeric D4Z1 probe (aqua).

Table 2. BAC-based FISH probes used to characterize the break points of the $t(2 ; 4)(q 22 ; q 24)$.

\begin{tabular}{|c|c|c|c|}
\hline Cytoband & Position [hg18] & Probe & Result on Derivative Chromosomes \\
\hline $4 q 23$ & $101,510,593-101,671,984$ & RP11-13F20 & $\begin{array}{l}\text { Partially deleted on der(4), and fused with } \\
\text { RP11-79C2 }\end{array}$ \\
\hline $4 q 23$ & $101,560,500-101,762,033$ & RP11-842N10 & Deleted on der(4) \\
\hline $4 q 24$ & $107,113,145-107,319,249$ & RP11-867L22 & On der(2) \\
\hline $4 \mathrm{p} 10 \mathrm{q} 10$ & & D4Z1 & On $\operatorname{der}(4)$ \\
\hline $2 q 35$ & $218,520,847-218,639,368$ & RP11-129D2 & On der(2) \\
\hline $2 q 36.1$ & $221,626,882-221,799,537$ & RP11-451C18 & On der(2) \\
\hline $2 \mathrm{q} 36.1$ & $224,095,528-224,291,965$ & RP11-726G4 & On der(2) \\
\hline $2 \mathrm{q} 36.1$ & $224,301,090-224,460,665$ & RP11-183N7 & On der(2) \\
\hline $2 q 36.1$ & $224,460,665-224,627,199$ & RP11-79C2 & $\begin{array}{l}\text { The probe is unevenly split between der(2) and } \\
\text { der(4) by } 75 \% \text { and } 25 \% \text { signal intensity, } \\
\text { respectively. It is fused with RP11-13F20 }\end{array}$ \\
\hline $2 q 36.1$ & $224,625,674-224,809,242$ & RP11-8F7 & On der(4) \\
\hline $2 q 36.2$ & $225,077,009-225,253,855$ & RP11-110D2 & On der(4) \\
\hline $2 \mathrm{q} 36.2$ & $225,527,112-225,706,569$ & RP11-1047B17 & On $\operatorname{der}(4)$ \\
\hline $2 q 36.3$ & $226,764,027-226,939,580$ & RP11-59L19 & On $\operatorname{der}(4)$ \\
\hline $2 q 36.3$ & $228,283,721-228,440,226$ & RP11-90L9 & On $\operatorname{der}(4)$ \\
\hline
\end{tabular}

Taken together, we have shown that an approximately $5.4 \mathrm{Mb}$ large chromosomal segment encompassing the bands 4 q23q24 is deleted and that this event is accompanied by a reciprocal translocation of the telomeric 4q24-qter segment with the 2q36.1-qter segment as summarized in Figure 4A. The final karyotype resulting from conventional cytogenetics, FISH and aCGH investigations, according to ISCN 2013, of bone marrow at diagnosis is: 46,XX, der(2)t(2;4)(q36.1;q24), 
A

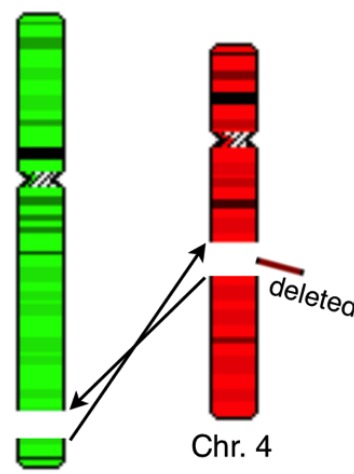

Chr. 2

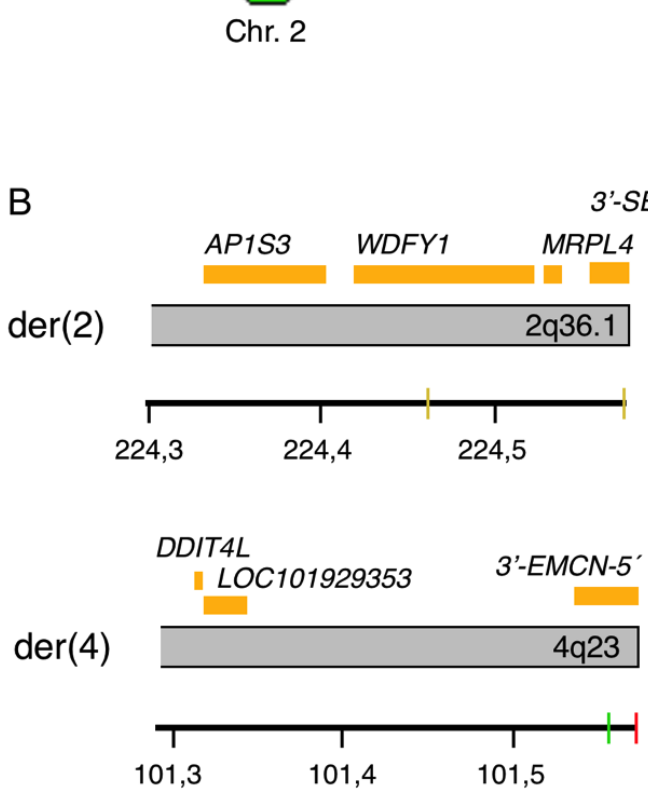

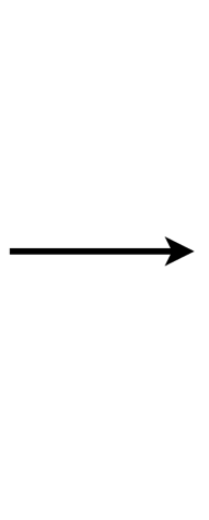
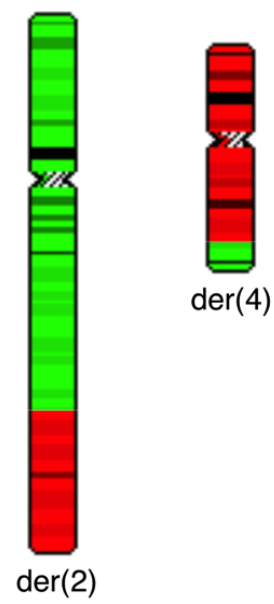

$\operatorname{der}(4)$

$\operatorname{der}(2)$

Figure 4. Model of chromosomal rearrangement. (A) Schematic representation of the translocation between chromosomes 2 and 4 with breakage points indicated by arrows together with the deleted region followed by reciprocal joining. (B) Schematic representation of genes (light brown boxes) mapping in correspondence to the breakpoint regions. Upper panel shows the joined regions of 2q36.1 and 4q24 and the lower panel shows the joined regions 4q23 and 2q36.1. The deleted chromosomal fragment del(4)(q23q24) is omitted and the genes located in this region are listed in Table 2. The axis at the bottom of each panel indicates the chromosomal position of the involved regions. The resolution of the aCGH analysis is limited to the kilobase pair level and the density of the oligo probes differ according to chromosomal regions with the highest density at known cancer genes. Vertical red and green bars indicate the relative genomic position of deleted (red) and not deleted (green) oligonucleotide probes in the aCGH analysis. Vertical yellow bars indicate the position of BAC clone RP11-79C2 being involved in the translocation.

In silico analysis of the involved regions suggested that the $5^{\prime}$-part of $E M C N$ gene (spanning exons 1 to 5 ) at $4 \mathrm{q} 23$ and the $5^{\prime}$-part of GSTCD gene (spanning exons 1 to 5) at 4q24 were deleted (Figure 4B). The fusion of the chromosomal regions $4 \mathrm{q} 23$ and $2 \mathrm{q} 36.1$ on $\operatorname{der}(4) \mathrm{t}(2 ; 4)$ could theoretically form the fusion gene SERPINE-EMCN. The fusion on $\operatorname{der}(2) \mathrm{t}(2 ; 4)$ involved the $5^{\prime}$-part of the GSTCD gene on $4 \mathrm{q} 24$, but it could not be determined which of the WDFY1, MRPL4 or SERPINE genes on 2q36.1 that might be involved in the translocation event due to lack of genomic resolution. Unfortunately, we could 
not perform gene expression or RNA sequencing analyses to establish possible presence of a fusion gene or altered expression of involved genes due to lack of additional sample material.

\section{Discussion}

Polycythemia vera has an inherent tendency to transform into myelofibrosis (MF), MDS or AML [18]. The cumulative incidence of post-PV MF evolution is $5-14 \%$ at 15 years [19-21] and for post-PV MDS/AML the estimated transformation rates are $2.3 \%$ at 10 years and remains $<10 \%$ at 20 years [22,23]. The survival rates of PV shorten after transformation to either MF or MDS/AML. Factors influencing these survival rates include: age, leukocytosis, abnormal karyotype, splenomegaly, bone marrow reticulin grade, and JAK2V617F mutant allele burden [19,23-28]. It is evident that the process of transformation in $\mathrm{PV}$ is complex and at present it is not possible to accurately predict which PV patients that will transform or not.

Cytogenetic abnormalities may play a role in the transformation process as the frequency of chromosomal aberrations in PV is approximately $20 \%$ at diagnosis but much higher among patients transforming to AML [7-10]. Trisomy 8 and 9, and abnormalities of chromosome 1, 20q-, 13q-, 11q-, 3p-, and dup13 have most frequently been observed, especially in older patients $>60$ years of age $[4,7]$. A minority of PV patients have been shown to have acquired various translocations at diagnosis including $\mathrm{t}(2 ; 11)(\mathrm{p} 21 ; \mathrm{q} 23)[29], \mathrm{t}(16 ; 20)(\mathrm{q} 22 ; \mathrm{p} 13)$ [30], and $\operatorname{der}(18) \mathrm{t}(9 ; 18)(\mathrm{p} 13 ; \mathrm{p} 11)$ or $\operatorname{der}(9 ; 18)(\mathrm{p} 10 ; \mathrm{q} 10)$ [31]. However, the role of these different types of cytogenetic abnormalities in transformation of PV remains obscure, and cytogenetic abnormalities have not been shown to carry prognostic relevance [5].

In this study, we found a $\mathrm{t}(2 ; 4)(\mathrm{q} 36.1 ; \mathrm{q} 24)$ in a female with JAK2V617F-positive PV at diagnosis with a follow-up period of 5 years where her disease has not transformed to MF or MDS/AML. The identified $t(2 ; 4)$ translocation is to the best of our knowledge novel as searches in Mitelman [32] and literature databases revealed no additional cases. In addition, a search in our local registry with more than 20,000 entries of different hematological malignancies since 2001 was also without additional cases. By aCGH analysis we detected an additional concurrent submicroscopic $5.4 \mathrm{Mb}$ large deletion at $4 q 23 q 24$, and it was confirmed by FISH analyses that the deletion was located on the $\operatorname{der}(4) \mathrm{t}(2 ; 4)$ at the $4 \mathrm{q} 24$ translocation breakpoint. Both of these chromosomal abnormalities were acquired because cytogenetic analyses of surrogate germ-line cells were without the detected aberrations.

Chromosomal aberrations involving chromosome band 2q36 have been reported in 15 MDS or AML cases [32]. The reported aberrations include: $t(1 ; 2)(q 21-q 22 ; q 36)$ [33-35], $t(X ; 2)(p 22 ; q 36)$ [36], $\mathrm{t}(2 ; 17)(\mathrm{q} 36 ; \mathrm{q} 11)[37,38]$, and $\operatorname{del}(2)(\mathrm{q} 23-\mathrm{q} 35 \mathrm{q} 36)$ [39-41]. In the present PV patient, we performed chromosome walking utilizing several different FISH probes and mapped the translocations breakpoint to be within the BAC-clone RP11-79C2 at 2q36.1 (genomic pos. 224,460,665-224,627,199; hg18). There are three genes located within this BAC-clone: WDFY1, MRPL44 and SERPINE2. In silico analysis revealed that SERPINE2 theoretically could form a fusion gene with the EMCN at 4q23 (Figure 4). The SERPINE2 gene, expressing a serine proteinase inhibitor clade E member 2, was recently shown to be a potential biomarker for tumor diagnosis and prognosis in a variety of solid tumors [42]. Although the EMCN gene previously has been shown to be overexpressed in acute leukemia [43] further studies are needed to clarify the potential role, if any, of the SERPINE2 and EMCN genes in the pathogenesis of the present patient.

Chromosome band 4q24 is a more common chromosomal breakpoint region in myeloid malignancies as 34 cases have been reported in MDS or AML [32]. The most frequent aberrations include: t(1;4)(p32;q24) [44], t(1;4)(p35;q24) [45], t(4;12)(q24;q12-q22) [46-48], t(4;17)(q24;q25) [47,48], $\mathrm{t}(\mathrm{X} ; 4)(\mathrm{q} 22 ; \mathrm{q} 24)$ [49], and del(4)(q21-q28) [50-56]. In a study of four female AML or MDS patients the $4 \mathrm{q} 24$ band was involved in three apparently balanced translocations between $4 \mathrm{q}$ and a variable partner chromosome, including $\mathrm{t}(3 ; 4)(\mathrm{q} 26 ; \mathrm{q} 24), \mathrm{t}(4 ; 5)(\mathrm{q} 24 ; \mathrm{p} 16)$, and $\mathrm{t}(4 ; 7)(\mathrm{q} 24 ; \mathrm{q} 21)$, and one patient with a localized del(4)(q24q25) [57]. Unexpectedly, the authors detected a concurrent submicroscopic deletion at 4q24 (localized between genomic positions $105,800,776$ to $106,847,377$; hg18) in all three patients 
harboring the apparently balanced translocations by metaphase FISH analyses using near-contiguous BAC-based probes. Interestingly, in our present patient we also detected a concurrent submicroscopic deletion, del(4)(q23q24), in addition to the $\mathrm{t}(2 ; 4)(\mathrm{q} 36.1 ; \mathrm{q} 24)$. Taken together, it seems that the 4q24 chromosomal region may be directly or indirectly associated with pathogenesis in a subset of hematological disorders.

In our patient aCGH analysis defined the concurrent deletion to be $5.4 \mathrm{Mb}$ large encompassing 40 RefSeq genes, including TET2 and CXXC4. TET2 belongs to a group of ten-eleven-translocation (TET) proteins, Fe(II)- and $\alpha$-ketoglutarate-dependent oxygenases, that modify 5 -methylcytosine (5-mC) to e.g., 5-hydroxymethylcytosine (5-hmC) [58,59], which seems to be an important step in the active demethylation of DNA [60]. Loss of TET2 function is associated with a continuous enlargement of the hematopoietic stem cell compartment leading to myeloproliferation by a mechanism of increased hematopoietic stem cell self-renewal and myeloid transformation as indicated by studies in mice [61,62]. TET2 mutations have been described in a wide range of myeloid malignancies with a mutation frequency of 7 to $13 \%[63,64]$. These mutations are typically small deletions, insertions, or nonsense mutations that are expected to induce loss-of-function in the protein. The catalytic activity of TET2 might be impaired by missense mutations affecting conserved amino acids in TET2, which can result in lower global 5-hmC levels in TET2-mutated patients compared with wild-type TET2 [65].

The CXXC4 gene is a negative regulator of Wnt signaling pathway and also regulates the TET2 expression, where co-expression of CXXC4 and TET2 resulted in a decrease in levels of 5-hmC [66]. The homeostatic self-renewal of stem cells in adult tissues is regulated by the Wnt signaling pathway [67], and its constitutive activation contributes to cancer development and progression [68-70]. Other genes involved in regulation of Wnt pathways include the ASXL1, ASXL2, UTX, CXXC4, CXXC5, TET2, and TET3 genes as indicated by MDS patients harboring mutations in these genes [71]. The CXXC4 gene has been associated with development of renal carcinoma [72], colonic villous adenoma [73], and gastric cancer [74].

Our study patient had, in addition to the $\mathrm{t}(2 ; 4)$ and $\operatorname{del}(4)(\mathrm{q} 24 \mathrm{q} 24)$, a high allelic burden of JAK2V617F mutation (equivalent to $71 \%$ ) which was similar the number of cells harboring the $4 \mathrm{q} 24$ deletion. This finding is in line with observations that the most common co-occurring classes of mutations in MPNs are signaling mutations (e.g., JAK2V617F) and mutations in genes involved in epigenetic regulation (e.g., TET2) [75]. Progression in PV patients may result from co-occurring mutations in JAK2V617V and TET2 because loss of TET2 might drive clonal dominance in hematopoietic stem cells and that $J A K 2 \mathrm{~V} 617 \mathrm{~V}$ expression might cause expansion of precursor cell populations [75]. Furthermore, it was observed that treatment of PV patients carrying both TET2 and JAK2 mutations experienced reduction in the JAK2 mutant clones without significant eradication of the TET2 mutant clone [76]. This was also observed in PV patients during PEG-IFN- $\alpha-2 a$ therapy where the TET2 mutant clones persist despite eradication of JAK2V617F clones [75]. In some patients pegylated interferon alfa-2a has the ability to induce complete bone marrow responses [77]. Our patient was initially treated with phlebotomy, cytoreductive (hydroxyurea) and anti-thrombotic therapy but due to persistent pruritus and high platelet counts cytoreductive treatment was changed to pegylated interferon alfa-2a for a period of approximately 14 months (Supplemental Figure S1). Unfortunately, we do not have any molecular follow-up data on allelic burden of JAK2- or TET2-mutations to document potential changes in mutation burdens of these mutations but she responded clinical well. Another limitation of this study is that the follow-up of the present patient is relatively short, a little more than 5 years, as it is known that PV may transform after up to 20 years.

Only a few studies have used aCGH or single nucleotide polymorphism (SNP) analysis in characterizing PV genomic aberrations. In a study of $26 \mathrm{PV}$ patients high density oligo-based aCGH analysis detected copy number alterations in $35 \%$ of the patients at diagnosis [78]. Another study of $14 \mathrm{PV}$ patients concluded that microdeletions and microduplications do not have an essential role in the development of PV as detected by high-density oligo-based aCGH analysis [79]. A study using 
high-resolution SNP microarrays revealed a common uniparental disomy (UPD) of chromosome 9p or gain of $9 \mathrm{p}$ in addition to other copy number aberrations in a small cohort of post-PV MF patients with elevated JAK2V617F mutation burden [80]. Our present study together with these previous studies underscores the value of using aCGH or SNP analysis in characterizing genomic alterations in PV at least in subsets of patients with e.g., translocations involving chromosome band 4q24.4.

\section{Materials and Methods}

\subsection{Cytogenetic Analysis}

Unstimulated overnight cultures of bone marrow sample from the patient were examined according to our standard laboratory protocols. Phytohemagglutinin (PHA)-stimulated culture from a peripheral blood sample was established at a later time point to examine whether identified chromosomal abnormalities were acquired or congenital. Chromosome preparations were treated and stained by Giemsa-banding. Karyotypes were described according to An International System for Human Cytogenetic Nomenclature (ISCN, 2013) [81]. Written informed consent was obtained from the patient.

\subsection{FISH Analysis}

To characterize the chromosome rearrangement multicolor FISH were done on chromosome preparations from bone marrow according to manufacturer's instructions using the following human XCyting multicolor FISH probes (MetaSystems, Altlussheim, Germany): (1) 24-color karyotyping was done with the 24XCyte kit consisting of 24 different chromosome painting probes; and (2) mBanding with XCyting probes for chromosome 2 consisting of a series of partial chromosome paint probes for sequential partially overlapping chromosome regions of a single chromosome. Each of the XCyte probes was labeled with one of five fluorochromes or a unique combination thereof (combinatorial labeling). Metaphases were counterstained with 4',6-diamidino-2-phenylindole (DAPI). Image capture was done with an automated Zeiss Axio Imager.Z2 equipped with a couple-charged device (CCD)-camera (CoolCube1, MetaSystems, Altlussheim, Germany) and appropriate filters (MetaSystems, Altlussheim, Germany). Karyotyping was done using the 24-color mFISH upgrade package, ISIS, including mBanding.

Locus-specific directly fluorescent-labeled BAC probes (Empire Genomics, Buffalo, NY, USA) on chromosomes 2 and 4 were used for validation of identified microdeletion by oaCGH analysis and break point mapping together with SE4 (D4Z1) (Kreatech, Amsterdam, The Netherlands). To estimate the number of abnormal cells 200 interphase nuclei was evaluated by two independent observers. All locus-specific analyses were done according to manufacturer's instructions. To identify the common dual fusion probe $B C R-A B L 1$ (Abbott Molecular, Wiesbaden, Germany).

\section{3. oaCGH Analysis}

The CytoChip Cancer $4 \times 180 \mathrm{~K}$ v2.0 (BlueGnome, Cambridge, UK) encompassing a $20 \mathrm{~kb}$ backbone with highest concentration of probes at 670 cancer genes was used for oaCGH analysis according to manufacturer's instructions as described in [82]. DNA purified from bone marrow cells was used together with pooled female genomic DNA as reference. After hybridization, washing and drying, the oligo array was scanned at $2.5 \mu \mathrm{m}$ with GenePix $4400 \mathrm{~A}$ microarray scanner. Initial analysis and normalization was done with BlueFuseMulti v2.6. For analysis and visualization normalized log2 probe signal values were imported into Nexus Copy Number software v. 6.1 (BioDiscovery, CA, USA) and segmented using FASST2 segmentation algorithm with a minimum of 3 probes/segment. Regions of gain or loss contained within copy number variable regions (CNVs) were discarded. Reference genome was NCBI build 36.1 (hg18). The UCSC database (http://genome.ucsc.edu) was used for bioinformatics analysis. 


\subsection{JAK2 Mutation Analysis}

DNA extracted from peripheral blood leukocytes after red blood cell lysis was used for JAK2V617F mutation analysis, which was done by allele-specific polymerase chain reaction as described [12].

\section{Conclusions}

In summary, we identified a novel apparently balanced $\mathrm{t}(2 ; 4)(\mathrm{q} 36.1 ; \mathrm{q} 24)$ with a concurrent cryptic del(4)(q23q24) in a JAK2V617F positive PV patient. The submicroscopic deletion was detected by aCGH analysis and found to be $5.4 \mathrm{Mb}$ in size encompassing 40 RefSeq genes, including TET2 and CXXC4. FISH analysis confirmed that the interstitial submicroscopic mono-allelic deletion at $4 \mathrm{q}$ was on $\operatorname{der}(4) \mathrm{t}(2 ; 4)$.

Our findings agree with observations from mice model systems where concomitant JAK2V617F expression and TET2 loss promote accelerated myeloproliferation but no overt fibrotic or leukemic transformation. It is, therefore, important to identify PV patients that are positive for both TET2- and $J A K 2$-mutations to offer optimal treatment options. To identify this group of JAK2V617F positive PV patients harboring concomitant TET2 loss we suggest including either locus-specific FISH analysis covering the TET2 locus or oaCGH analysis to detect copy number changes in chromosome band 4q24.

The observed del(4)(q23q24) in our patient also encompassed the CXXC4 gene which is a known regulator of TET2 expression, but the impact of this observation must await further studies.

The present findings provide additional clues to unravel important molecular pathways in PV to obtain the full spectrum of acquired chromosomal and genomic aberrations. As more cases become characterized at the molecular level this may eventually improve on treatment options.

Supplementary Materials: The following are available online at http:/ /www.mdpi.com/2072-6694/10/7/214/s1, Figure S1: Longitudinal biochemical analyses and treatment overview.

Acknowledgments: The biotechnologists Kirsten V. Madsen, Bente Madsen, and Pia Kristensen are greatly thanked for their excellent technical assistance. The clinicians at Department of Hematology are greatly thanked for providing clinical details. The Danish Cancer Society (No. 16.04.2010) supported the study.

Conflicts of Interest: The author declares no conflicts of interest.

\section{References}

1. The International Agency for Research on Cancer. WHO Classification of Tumours of Haematopoietic and Lymphoid Tissue, 4th ed.; Swerdlow, S., Campo, E., Harris, N.L., Jaffe, E.S., Pileri, S.A., Stein, H., Thiele, J., Vardiman, J.W., Eds.; IARC Publications: Lyon, France, 2008.

2. Tefferi, A.; Vannucchi, A.M.; Barbui, T. Polycythemia vera treatment algorithm 2018. Blood Cancer J. 2018, 8, 3. [CrossRef] [PubMed]

3. Bacher, U.; Haferlach, T.; Kern, W.; Hiddemann, W.; Schnittger, S.; Schoch, C. Conventional cytogenetics of myeloproliferative diseases other than CML contribute valid information. Ann. Hematol. 2005, 84, $250-257$. [CrossRef] [PubMed]

4. Diez-Martin, J.L.; Graham, D.L.; Petitt, R.M.; Dewald, G.W. Chromosome studies in 104 patients with polycythemia vera. Mayo Clin. Proc. 1991, 66, 287-299. [CrossRef]

5. Gangat, N.; Strand, J.; Lasho, T.L.; Finke, C.M.; Knudson, R.A.; Pardanani, A.; Li, C.Y.; Ketterling, R.P.; Tefferi, A. Cytogenetic studies at diagnosis in polycythemia vera: Clinical and JAK2V617F allele burden correlates. Eur. J. Haematol. 2008, 80, 197-200. [CrossRef] [PubMed]

6. Lawler, S.D. Cytogenetic studies in Philadelphia chromosome-negative myeloproliferative disorders, particularly polycythaemia rubra vera. Clin. Haematol. 1980, 9, 159-174. [PubMed]

7. Rege-Cambrin, G.; Mecucci, C.; Tricot, G.; Michaux, J.L.; Louwagie, A.; van Hove, W.; Francart, H.; van den Berghe, H. A chromosomal profile of polycythemia vera. Cancer Genet. Cytogenet. 1987, 25, $233-245$. [CrossRef]

8. Testa, J.R.; Kanofsky, J.R.; Rowley, J.D.; Baron, J.M.; Vardiman, J.W. Karyotypic patterns and their clinical significance in polycythemia vera. Am. J. Hematol. 1981, 11, 29-45. [CrossRef] [PubMed] 
9. Swolin, B.; Weinfeld, A.; Westin, J. A prospective long-term cytogenetic study in polycythemia vera in relation to treatment and clinical course. Blood 1988, 72, 386-395. [PubMed]

10. Sever, M.; Quintas-Cardama, A.; Pierce, S.; Zhou, L.; Kantarjian, H.; Verstovsek, S. Significance of cytogenetic abnormalities in patients with polycythemia vera. Leuk. Lymphoma 2013, 54, 2667-2670. [CrossRef] [PubMed]

11. Andrieux, J.L.; Demory, J.L. Karyotype and molecular cytogenetic studies in polycythemia vera. Curr. Hematol. Rep. 2005, 4, 224-229. [PubMed]

12. Baxter, E.J.; Scott, L.M.; Campbell, P.J.; East, C.; Fourouclas, N.; Swanton, S.; Vassiliou, G.S.; Bench, A.J.; Boyd, E.M.; Curtin, N.; et al. Cancer Genome: Acquired mutation of the tyrosine kinase JAK2 in human myeloproliferative disorders. Lancet 2005, 365, 1054-1061. [CrossRef]

13. James, C.; Ugo, V.; Le Couedic, J.P.; Staerk, J.; Delhommeau, F.; Lacout, C.; Garcon, L.; Raslova, H.; Berger, R.; Bennaceur-Griscelli, A.; et al. unique clonal JAK2 mutation leading to constitutive signalling causes polycythaemia vera. Nature 2005, 434, 1144-1148. [CrossRef] [PubMed]

14. Kralovics, R.; Teo, S.S.; Buser, A.S.; Brutsche, M.; Tiedt, R.; Tichelli, A.; Passamonti, F.; Pietra, D.; Cazzola, M.; Skoda, R.C. Altered gene expression in myeloproliferative disorders correlates with activation of signaling by the V617F mutation of Jak2. Blood 2005, 106, 3374-3376. [CrossRef] [PubMed]

15. Kralovics, R.; Passamonti, F.; Buser, A.S.; Teo, S.S.; Tiedt, R.; Passweg, J.R.; Tichelli, A.; Cazzola, M.; Skoda, R.C. A gain-of-function mutation of JAK2 in myeloproliferative disorders. N. Engl. J. Med. 2005, 352, 1779-1790. [CrossRef] [PubMed]

16. Levine, R.L.; Wadleigh, M.; Cools, J.; Ebert, B.L.; Wernig, G.; Huntly, B.J.; Boggon, T.J.; Wlodarska, I.; Clark, J.J.; Moore, S.; et al. Activating mutation in the tyrosine kinase JAK2 in polycythemia vera, essential thrombocythemia, and myeloid metaplasia with myelofibrosis. Cancer Cell 2005, 7, 387-397. [CrossRef] [PubMed]

17. Tefferi, A. Novel mutations and their functional and clinical relevance in myeloproliferative neoplasms: JAK2, MPL, TET2, ASXL1, CBL, IDH and IKZF1. Leukemia 2010, 24, 1128-1138. [CrossRef] [PubMed]

18. Cerquozzi, S.; Tefferi, A. Blast transformation and fibrotic progression in polycythemia vera and essential thrombocythemia: A literature review of incidence and risk factors. Blood Cancer J. 2015, 5, e366. [CrossRef] [PubMed]

19. Kiladjian, J.J.; Gardin, C.; Renoux, M.; Bruno, F.; Bernard, J.F. Long-term outcomes of polycythemia vera patients treated with pipobroman as initial therapy. Hematol. J. 2003, 4, 198-207. [CrossRef] [PubMed]

20. Passamonti, F.; Rumi, E.; Pungolino, E.; Malabarba, L.; Bertazzoni, P.; Valentini, M.; Orlandi, E.; Arcaini, L.; Brusamolino, E.; Pascutto, C.; et al. Life expectancy and prognostic factors for survival in patients with polycythemia vera and essential thrombocythemia. Am. J. Med. 2004, 117, 755-761. [CrossRef] [PubMed]

21. Bonicelli, G.; Abdulkarim, K.; Mounier, M.; Johansson, P.; Rossi, C.; Jooste, V.; Andreasson, B.; Maynadie, M.; Girodon, F. Leucocytosis and thrombosis at diagnosis are associated with poor survival in polycythaemia vera: A population-based study of 327 patients. Br. J. Haematol. 2013, 160, 251-254. [CrossRef] [PubMed]

22. Tefferi, A.; Guglielmelli, P.; Larson, D.R.; Finke, C.; Wassie, E.A.; Pieri, L.; Gangat, N.; Fjerza, R.; Belachew, A.A.; Lasho, T.L.; et al. Long-term survival and blast transformation in molecularly annotated essential thrombocythemia, polycythemia vera, and myelofibrosis. Blood 2014, 124, 2507-2513. [CrossRef] [PubMed]

23. Tefferi, A.; Rumi, E.; Finazzi, G.; Gisslinger, H.; Vannucchi, A.M.; Rodeghiero, F.; Randi, M.L.; Vaidya, R.; Cazzola, M.; Rambaldi, A.; et al. Survival and prognosis among 1545 patients with contemporary polycythemia vera: An international study. Leukemia 2013, 27, 1874-1881. [CrossRef] [PubMed]

24. Finazzi, G.; Caruso, V.; Marchioli, R.; Capnist, G.; Chisesi, T.; Finelli, C.; Gugliotta, L.; Landolfi, R.; Kutti, J.; Gisslinger, H.; et al. Acute leukemia in polycythemia vera: An analysis of 1638 patients enrolled in a prospective observational study. Blood 2005, 105, 2664-2670. [CrossRef] [PubMed]

25. Marchioli, R.; Finazzi, G.; Landolfi, R.; Kutti, J.; Gisslinger, H.; Patrono, C.; Marilus, R.; Villegas, A.; Tognoni, G.; Barbui, T. Vascular and neoplastic risk in a large cohort of patients with polycythemia vera. J. Clin. Oncol. 2005, 23, 2224-2232. [CrossRef] [PubMed]

26. Gangat, N.; Strand, J.; Li, C.Y.; Wu, W.; Pardanani, A.; Tefferi, A. Leucocytosis in polycythaemia vera predicts both inferior survival and leukaemic transformation. Br. J. Haematol. 2007, 138, 354-358. [CrossRef] [PubMed] 
27. Abdulkarim, K.; Ridell, B.; Johansson, P.; Kutti, J.; Safai-Kutti, S.; Andreasson, B. The impact of peripheral blood values and bone marrow findings on prognosis for patients with essential thrombocythemia and polycythemia vera. Eur. J. Haematol. 2011, 86, 148-155. [CrossRef] [PubMed]

28. Passamont, F.; Rumi, E.; Pietra, D.; Elena, C.; Boveri, E.; Arcaini, L.; Roncoroni, E.; Astori, C.; Merli, M.; Boggi, S.; et al. A prospective study of 338 patients with polycythemia vera: The impact of JAK2 (V617F) allele burden and leukocytosis on fibrotic or leukemic disease transformation and vascular complications. Leukemia 2010, 24, 1574-1579. [CrossRef] [PubMed]

29. Acar, K.; Sucak, G.T.; Yagci, M.; Tunca, Y.; Haznedar, R. Translocation $(2 ; 11)(p 21 ; q 23)$ in a patient with polycythemia vera: A novel clonal chromosome abnormality. Am. J. Hematol. 2006, 81, 891. [CrossRef] [PubMed]

30. Daibata, M.; Taguchi, T.; Taguchi, H. A novel t(16;20)(q22;p13) in polycythemia vera. Cancer Genet. Cytogenet. 2002, 137, 29-32. [CrossRef]

31. Larsen, T.S.; Hasselbalch, H.C.; Pallisgaard, N.; Kerndrup, G.B. A der(18)t(9;18)(p13;p11) and a $\operatorname{der}(9 ; 18)(\mathrm{p} 10 ; \mathrm{q} 10)$ in polycythemia vera associated with a hyperproliferative phenotype in transformation to postpolycythemic myelofibrosis. Cancer Genet. Cytogenet. 2007, 172, 107-112. [CrossRef] [PubMed]

32. Mitelman, F.; Johansson, B.; Mertens, F.E. Mitelman Database of Chromosome Aberrations and Gene Fusions in Cancer. Available online: http:/ / cgapncinihgov /Chromosomes/Mitelman2018 (accessed on 14 February 2018).

33. Dastugue, N.; Lafage-Pochitaloff, M.; Pages, M.P.; Radford, I.; Bastard, C.; Talmant, P.; Mozziconacci, M.J.; Leonard, C.; Bilhou-Nabera, C.; Cabrol, C.; et al. Cytogenetic profile of childhood and adult megakaryoblastic leukemia (M7): A study of the Groupe Francais de Cytogenetique Hematologique (GFCH). Blood 2002, 100, 618-626. [CrossRef] [PubMed]

34. Alter, B.P.; Caruso, J.P.; Drachtman, R.A.; Uchida, T.; Velagaleti, G.V.; Elghetany, M.T. Fanconi anemia: Myelodysplasia as a predictor of outcome. Cancer Genet. Cytogenet. 2000, 117, 125-131. [CrossRef]

35. Fenaux, P.; Lai, J.L.; Quiquandon, I.; Preudhomme, C.; Dupriez, B.; Facon, T.; Lorthois, C.; Lucidarme, D.; Bauters, F. Therapy related myelodysplastic syndrome and leukemia with no "unfavourable" cytogenetic findings have a good response to intensive chemotherapy: A report on 15 cases. Leuk. Lymphoma 1991, 5, 117-125. [CrossRef] [PubMed]

36. Borel, C.; Dastugue, N.; Cances-Lauwers, V.; Mozziconacci, M.J.; Prebet, T.; Vey, N.; Pigneux, A.; Lippert, E.; Visanica, S.; Legrand, F.; et al. PICALM-MLLT10 acute myeloid leukemia: A French cohort of 18 patients. Leuk. Res. 2012, 36, 1365-1369. [CrossRef] [PubMed]

37. Babicka, L.; Ransdorfova, S.; Brezinova, J.; Zemanova, Z.; Sindelarova, L.; Siskova, M.; Maaloufova, J.; Cermak, J.; Michalova, K. Analysis of complex chromosomal rearrangements in adult patients with MDS and AML by multicolor FISH. Leuk. Res. 2007, 31, 39-47. [CrossRef] [PubMed]

38. Lessard, M.; Helias, C.; Struski, S.; Perrusson, N.; Uettwiller, F.; Mozziconacci, M.J.; Lafage-Pochitaloff, M.; Dastugue, N.; Terre, C.; Brizard, F.; et al. Fluorescence in situ hybridization analysis of 110 hematopoietic disorders with chromosome 5 abnormalities: Do de novo and therapy-related myelodysplastic syndrome-acute myeloid leukemia actually differ? Cancer Genet. Cytogenet. 2007, 176, 1-21. [CrossRef] [PubMed]

39. Lange, K.; Holm, L.; Vang Nielsen, K.; Hahn, A.; Hofmann, W.; Kreipe, H.; Schlegelberger, B.; Gohring, G. Telomere shortening and chromosomal instability in myelodysplastic syndromes. Genes Chromosom. Cancer 2010, 49, 260-269. [CrossRef] [PubMed]

40. Le Beau, M.M.; Albain, K.S.; Larson, R.A.; Vardiman, J.W.; Davis, E.M.; Blough, R.R.; Golomb, H.M.; Rowley, J.D. Clinical and cytogenetic correlations in 63 patients with therapy-related myelodysplastic syndromes and acute nonlymphocytic leukemia: Further evidence for characteristic abnormalities of chromosomes no. 5 and 7. J. Clin. Oncol. 1986, 4, 325-345. [CrossRef] [PubMed]

41. Jeandidier, E.; Dastugue, N.; Mugneret, F.; Lafage-Pochitaloff, M.M.; Mozziconacci, M.J.; Herens, C.; Michaux, L.; Verellen-Dumoulin, C.; Talmant, P.; Cornillet-Lefebvre, P.; et al. Abnormalities of the long arm of chromosome 21 in 107 patients with hematopoietic disorders: A collaborative retrospective study of the Groupe Francais de Cytogenetique Hematologique. Cancer Genet. Cytogenet. 2006, 166, 1-11. [CrossRef] [PubMed]

42. Yang, Y.; Xin, X.; Fu, X.; Xu, D. Expression pattern of human SERPINE2 in a variety of human tumors. Oncol. Lett. 2018, 15, 4523-4530. [CrossRef] [PubMed] 
43. De Pitta, C.; Tombolan, L.; Campo Dell'Orto, M.; Accordi, B.; te Kronnie, G.; Romualdi, C.; Vitulo, N.; Basso, G.; Lanfranchi, G. A leukemia-enriched cDNA microarray platform identifies new transcripts with relevance to the biology of pediatric acute lymphoblastic leukemia. Haematologica 2005, 90, 890-898. [PubMed]

44. Dambruoso, I.; Boni, M.; Rossi, M.; Zappasodi, P.; Calvello, C.; Zappatore, R.; Cavigliano, P.M.; Giardini, I.; Rocca, B.; Caresana, M.; et al. Detection of TET2 abnormalities by fluorescence in situ hybridization in 41 patients with myelodysplastic syndrome. Cancer Genet. 2012, 205, 285-294. [CrossRef] [PubMed]

45. Soares-Ventura, E.M.; Mkrtchyan, H.; de Jesus Marques-Salles, T.; Silva, M.; Santos, N.; de Araujo Silva Amaral, B.; Liehr, T.; Abdelhay, E.; Silva, M.L.; Muniz, M.T. Molecular cytogenetics reveals complex karyotype in apparent $\mathrm{t}(8 ; 13)$ therapy-related acute myeloid leukemia M2 after fibrosarcoma. Leuk. Res. 2011, 35, e27-29. [CrossRef] [PubMed]

46. Walker, A.; Mrozek, K.; Kohlschmidt, J.; Rao, K.W.; Pettenati, M.J.; Sterling, L.J.; Marcucci, G.; Carroll, A.J.; Bloomfield, C.D.; Alliance for Clinical Trials in Oncology. New recurrent balanced translocations in acute myeloid leukemia and myelodysplastic syndromes: Cancer and leukemia group B 8461. Genes Chromosom. Cancer 2013, 52, 385-401. [CrossRef] [PubMed]

47. La Starza, R.; Crescenzi, B.; Nofrini, V.; Barba, G.; Matteucci, C.; Brandimarte, L.; Pierini, V.; Testoni, N.; Musto, P.; Paolini, S.; et al. FISH analysis reveals frequent co-occurrence of $4 \mathrm{q} 24 / \mathrm{TET} 2$ and $5 \mathrm{q}$ and / or 7q deletions. Leuk. Res. 2012, 36, 37-41. [CrossRef] [PubMed]

48. De Oliveira, F.M.; Miguel, C.E.; Lucena-Araujo, A.R.; de Lima, A.S.; Falcao, R.P.; Rego, E.M. FISH analysis for TET2 deletion in a cohort of 362 Brazilian myeloid malignancies: Correlation with karyotype abnormalities. Med. Oncol. 2013, 30, 483. [CrossRef] [PubMed]

49. Peniket, A.J. Del(9q) acute myeloid leukaemia: Clinical and cytological characteristics and prognostic implications. Br. J. Haematol. 2005, 130, 969. [CrossRef] [PubMed]

50. Fonatsch, C.; Gudat, H.; Lengfelder, E.; Wandt, H.; Silling-Engelhardt, G.; Ludwig, W.D.; Thiel, E.; Freund, M.; Bodenstein, H.; Schwieder, G.; et al. Correlation of cytogenetic findings with clinical features in 18 patients with inv(3)(q21q26) or t(3;3)(q21;q26). Leukemia 1994, 8, 1318-1326. [PubMed]

51. Lessard, M.; Struski, S.; Leymarie, V.; Flandrin, G.; Lafage-Pochitaloff, M.; Mozziconacci, M.J.; Talmant, P.; Bastard, C.; Charrin, C.; Baranger, L.; et al. Cytogenetic study of 75 erythroleukemias. Cancer Genet. Cytogenet. 2005, 163, 113-122. [CrossRef] [PubMed]

52. Lai, J.L.; Zandecki, M.; Fenaux, P.; Le Baron, F.; Bauters, F.; Cosson, A.; Deminatti, M. Translocations (5;17) and $(7 ; 17)$ in patients with de novo or therapy-related myelodysplastic syndromes or acute nonlymphocytic leukemia. A possible association with acquired pseudo-Pelger-Huet anomaly and small vacuolated granulocytes. Cancer Genet Cytogenet. 1990, 46, 173-183. [CrossRef]

53. Kuchinskaya, E.; Heyman, M.; Grander, D.; Linderholm, M.; Soderhall, S.; Zaritskey, A.; Nordgren, A.; Porwit-Macdonald, A.; Zueva, E.; Pawitan, Y.; et al. Children and adults with acute lymphoblastic leukaemia have similar gene expression profiles. Eur. J. Haematol. 2005, 74, 466-480. [CrossRef] [PubMed]

54. Chen, C.C.; Yang, C.F.; Lee, K.D.; You, J.Y.; Yu, Y.B.; Ho, C.H.; Tzeng, C.H.; Chau, W.K.; Hsu, H.C.; Gau, J.P. Complex karyotypes confer a poor survival in adult acute myeloid leukemia with unfavorable cytogenetic abnormalities. Cancer Genet. Cytogenet. 2007, 174, 138-146. [CrossRef] [PubMed]

55. Wyandt, H.E.; Chinnappan, D.; Ioannidou, S.; Salama, M.; O'Hara, C. Fluorescence in situ hybridization to assess aneuploidy for chromosomes 7 and 8 in hematologic disorders. Cancer Genet. Cytogenet. 1998, 102, 114-124. [CrossRef]

56. Glenn, L.D.; Sanger, W.G.; Kessinger, A.; Vaughan, W.P. Failure of karyotypic instability to predict clinical progression in patients with dysmyelopoietic syndromes. Hematol. Pathol. 1988, 2, 239-248. [PubMed]

57. Viguie, F.; Aboura, A.; Bouscary, D.; Ramond, S.; Delmer, A.; Tachdjian, G.; Marie, J.P.; Casadevall, N. Common 4q24 deletion in four cases of hematopoietic malignancy: Early stem cell involvement? Leukemia 2005, 19, 1411-1415. [CrossRef] [PubMed]

58. He, Y.F.; Li, B.Z.; Li, Z.; Liu, P.; Wang, Y.; Tang, Q.; Ding, J.; Jia, Y.; Chen, Z.; Li, L.; et al. Tet-mediated formation of 5-carboxylcytosine and its excision by TDG in mammalian DNA. Science 2011, 333, 1303-1307. [CrossRef] [PubMed]

59. Ito, S.; D'Alessio, A.C.; Taranova, O.V.; Hong, K.; Sowers, L.C.; Zhang, Y. Role of Tet proteins in $5 \mathrm{mC}$ to $5 \mathrm{hmC}$ conversion, ES-cell self-renewal and inner cell mass specification. Nature 2010, 466, 1129-1133. [CrossRef] [PubMed] 
60. Figueroa, M.E.; Lugthart, S.; Li, Y.; Erpelinck-Verschueren, C.; Deng, X.; Christos, P.J.; Schifano, E.; Booth, J.; van Putten, W.; Skrabanek, L.; et al. DNA methylation signatures identify biologically distinct subtypes in acute myeloid leukemia. Cancer Cell 2010, 17, 13-27. [CrossRef] [PubMed]

61. Moran-Crusio, K.; Reavie, L.; Shih, A.; Abdel-Wahab, O.; Ndiaye-Lobry, D.; Lobry, C.; Figueroa, M.E.; Vasanthakumar, A.; Patel, J.; Zhao, X.; et al. Tet2 loss leads to increased hematopoietic stem cell self-renewal and myeloid transformation. Cancer Cell 2011, 20, 11-24. [CrossRef] [PubMed]

62. Quivoron, C.; Couronne, L.; Della Valle, V.; Lopez, C.K.; Plo, I.; Wagner-Ballon, O.; Do Cruzeiro, M.; Delhommeau, F.; Arnulf, B.; Stern, M.H.; et al. TET2 inactivation results in pleiotropic hematopoietic abnormalities in mouse and is a recurrent event during human lymphomagenesis. Cancer Cell 2011, 20, 25-38. [CrossRef] [PubMed]

63. Tefferi, A.; Pardanani, A.; Lim, K.H.; Abdel-Wahab, O.; Lasho, T.L.; Patel, J.; Gangat, N.; Finke, C.M.; Schwager, S.; Mullally, A.; et al. TET2 mutations and their clinical correlates in polycythemia vera, essential thrombocythemia and myelofibrosis. Leukemia 2009, 23, 905-911. [CrossRef] [PubMed]

64. Delhommeau, F.; Dupont, S.; Della Valle, V.; James, C.; Trannoy, S.; Masse, A.; Kosmider, O.; Le Couedic, J.P.; Robert, F.; Alberdi, A.; et al. Mutation in TET2 in myeloid cancers. N. Engl. J. Med. 2009, 360, 2289-2301. [CrossRef] [PubMed]

65. Ko, M.; Huang, Y.; Jankowska, A.M.; Pape, U.J.; Tahiliani, M.; Bandukwala, H.S.; An, J.; Lamperti, E.D.; Koh, K.P.; Ganetzky, R.; et al. Impaired hydroxylation of 5-methylcytosine in myeloid cancers with mutant TET2. Nature 2010, 468, 839-843. [CrossRef] [PubMed]

66. Ko, M.; An, J.; Bandukwala, H.S.; Chavez, L.; Aijo, T.; Pastor, W.A.; Segal, M.F.; Li, H.; Koh, K.P.; Lahdesmaki, H.; et al. Modulation of TET2 expression and 5-methylcytosine oxidation by the CXXC domain protein IDAX. Nature 2013, 497, 122-126. [CrossRef] [PubMed]

67. Moon, R.T.; Kohn, A.D.; De Ferrari, G.V.; Kaykas, A. WNT and beta-catenin signalling: Diseases and therapies. Nat. Rev. Genet. 2004, 5, 691-701. [CrossRef] [PubMed]

68. Barker, N.; Clevers, H. Mining the Wnt pathway for cancer therapeutics. Nat. Rev. Drug Discov. 2006, 5, 997-1014. [CrossRef] [PubMed]

69. Moon, R.T.; Bowerman, B.; Boutros, M.; Perrimon, N. The promise and perils of Wnt signaling through beta-catenin. Science 2002, 296, 1644-1646. [CrossRef] [PubMed]

70. Logan, C.Y.; Nusse, R. The Wnt signaling pathway in development and disease. Annu. Rev. Cell Dev. Biol. 2004, 20, 781-810. [CrossRef] [PubMed]

71. Gelsi-Boyer, V.; Trouplin, V.; Adelaide, J.; Bonansea, J.; Cervera, N.; Carbuccia, N.; Lagarde, A.; Prebet, T.; Nezri, M.; Sainty, D.; et al. Mutations of polycomb-associated gene ASXL1 in myelodysplastic syndromes and chronic myelomonocytic leukaemia. Br. J. Haematol. 2009, 145, 788-800. [CrossRef] [PubMed]

72. Kojima, T.; Shimazui, T.; Hinotsu, S.; Joraku, A.; Oikawa, T.; Kawai, K.; Horie, R.; Suzuki, H.; Nagashima, R.; Yoshikawa, K.; et al. Decreased expression of CXXC4 promotes a malignant phenotype in renal cell carcinoma by activating Wnt signaling. Oncogene 2009, 28, 297-305. [CrossRef] [PubMed]

73. Nguyen, A.V.; Albers, C.G.; Holcombe, R.F. Differentiation of tubular and villous adenomas based on Wnt pathway-related gene expression profiles. Int. J. Mol. Med. 2010, 26, 121-125. [PubMed]

74. Lu, H.; Sun, J.; Wang, F.; Feng, L.; Ma, Y.; Shen, Q.; Jiang, Z.; Sun, X.; Wang, X.; Jin, H. Enhancer of zeste homolog 2 activates wnt signaling through downregulating CXXC finger protein 4. Cell Death Dis. 2013, 4, e776.

75. Chen, E.; Schneider, R.K.; Breyfogle, L.J.; Rosen, E.A.; Poveromo, L.; Elf, S.; Ko, A.; Brumme, K.; Levine, R.; Ebert, B.L.; et al. Distinct effects of concomitant Jak2V617F expression and Tet2 loss in mice promote disease progression in myeloproliferative neoplasms. Blood 2015, 125, 327-335. [CrossRef] [PubMed]

76. Kiladjian, J.J.; Masse, A.; Cassinat, B.; Mokrani, H.; Teyssandier, I.; le Couedic, J.P.; Cambier, N.; Almire, C.; Pronier, E.; Casadevall, N.; et al. Clonal analysis of erythroid progenitors suggests that pegylated interferon alpha-2a treatment targets JAK2V617F clones without affecting TET2 mutant cells. Leukemia 2010, 24, 1519-1523. [CrossRef] [PubMed]

77. Masarova, L.; Yin, C.C.; Cortes, J.E.; Konopleva, M.; Borthakur, G.; Newberry, K.J.; Kantarjian, H.M.; Bueso-Ramos, C.E.; Verstovsek, S. Histomorphological responses after therapy with pegylated interferon alpha-2a in patients with essential thrombocythemia (ET) and polycythemia vera (PV). Exp. Hematol. Oncol. 2017, 6, 30. [PubMed] 
78. Tefferi, A.; Sirhan, S.; Sun, Y.; Lasho, T.; Finke, C.M.; Weisberger, J.; Bale, S.; Compton, J.; LeDuc, C.A.; Pardanani, A.; et al. Oligonucleotide array CGH studies in myeloproliferative neoplasms: Comparison with JAK2V617F mutational status and conventional chromosome analysis. Leuk. Res. 2009, 33, 662-664. [CrossRef] [PubMed]

79. Borze, I.; Mustjoki, S.; Juvonen, E.; Knuutila, S. Oligoarray comparative genomic hybridization in polycythemia vera and essential thrombocythemia. Haematologica 2008, 93, 1098-1100. [CrossRef] [PubMed]

80. Rumi, E.; Harutyunyan, A.; Elena, C.; Pietra, D.; Klampfl, T.; Bagienski, K.; Berg, T.; Casetti, I.; Pascutto, C.; Passamonti, F.; et al. Identification of genomic aberrations associated with disease transformation by means of high-resolution SNP array analysis in patients with myeloproliferative neoplasm. Am. J. Hematol. 2011, 86, 974-979. [CrossRef] [PubMed]

81. ISCN. An International System for Human Cytogenetic Nomenclature; Shaffer, L.G., McGowan-Jordan, J., Schmid, M., Eds.; Karger: Basel, Switzerland, 2013.

82. Kjeldsen, E.; Roug, A.S. A novel unbalanced de novo translocation der(5)t(4;5)(q26;q21.1) in adult T-cell precursor lymphoblastic leukemia. Mol. Cytogenet. 2012, 5, 21. [CrossRef] [PubMed]

(C) 2018 by the author. Licensee MDPI, Basel, Switzerland. This article is an open access article distributed under the terms and conditions of the Creative Commons Attribution (CC BY) license (http:/ / creativecommons.org/licenses/by/4.0/). 